\title{
КОНЦЕПЦІЯ СИСТЕМАТИЗАЦІЇ ФІНАНСОВИХ РЕЗУЛЬТАТІВ ПІДПРИЕМСТВА: ОБЛІКОВО-АНАЛІТИЧНІ АСПЕКТИ ЗАБЕЗПЕЧЕННЯ
}

DOI: $10.32620 /$ cher.2021.1.07

Постановка проблеми. Розуміння сутності фінансових результатів діяльності підприємств і використання дієвих управлінських рішень щодо майбутнього їх розвитку є ключовою запорукою збільшення ефективності роботи організацій. Одним із актуальних питань щодо обліку, аналізу та аудиту фінансових результатів в умовах конкурентного середовища, $€$ концептуальні аспекти їхньої класифікації. Функціонування підприємства значною мірою залежить від його здатності приносити достатній рівень доходу. Метою статті $\epsilon$ визначення концепції систематизації фінансових результатів підприємства для подальшого підвищення ефективності обліково-аналітичної роботи організації, виявлення проблем у трактуванні поняття «фінансові результати» 3 метою удосконалення їхнього обліку, аналізу та аудиту. Предмет дослідження - концептуальні аспекти класифікації фінансових результатів діяльності вітчизняних підприємств. Методи, використані в дослідженні: порівняння, співставлення, системного та аналітичного підходів, середніх величин, узагальнення та класифікації, діалектичної і формальної логіки. Виклад основного матеріалу. У статті виявлено особливості класифікації фінансових результатів діяльності підприємства, визначено існуючі недоліки в нормативно-законодавчому регулюванні України щодо термінології фінансових результатів фірми, досліджено та узагальнено підходи до трактування поняття «фінансові результати», здійснено оцінювання й аналіз фінансових результатів вітчизняних суб'єктів господарювання, запропоновано заходи для вдосконалення обліково-аналітичних та аудиторських процедур щодо фінансових результатів і покращення результативності бізнесу організацій. Практичне значення одержаних результатів полягає в можливості застосування наданих рекомендацій для вдосконалення обліково-аналітичних та аудиторських процедур щодо фінансових результатів і покращення ефективності бізнесу вітчизняних підприємств. Висновки дослідження. Класифікація фінансових результатів діяльності підприємств $є$ вихідним моментом побудови їх обліку, аналізу та аудиту, проте наявні підходи щодо систематизації фінансових результатів містять багато суперечливих моментів, а тому є недосконалими. Класифікаційні ознаки мають охоплювати комплексне вивчення фінансових результатів та забезпечувати в потрібному розрізі їхнє групування. Запропонована класифікація фінансових результатів діяльності з метою їх обліку, аналізу та аудиту дасть змогу підвищити ефективність обліковоаналітичної діяльності організацій.

Ключові слова:

фінансові результати, систематизація, облік та аудит, аналіз, обліково-аналітична діяльність.

\section{THE CONCEPT OF SYSTEMATIZATION OF FINANCIAL RESULTS OF THE ENTERPRISE: ACCOUNTING AND ANALYTICAL ASPECTS OF ENSURING}

Formulation of the problem. Understanding the essence of the financial results of enterprises and using effective management decisions regarding their future development is a key guarantee to increasing the efficiency of organizations. One of the most pressing issues related to accounting, analysis and audit of fi-

${ }^{1}$ Ліхоносова Ганна Сергї̈вна, д-р екон. наук, професор кафедри фінансів, обліку і оподаткування, Національний аерокосмічний університет ім. М. Є. Жуковського «Харківський авіаційний інститут», м. Харків, Україна.

Likhonosova Ganna, Doctor of Economic Sciences, Professor of Finance, accounting and taxation Department National Aerospace University «Kharkiv Aviation Institute», Kharkiv, Ukraine.

ORCID ID: 0000-0001-6552-8920

e-mail: a.likhonosova@gmail.com

2 Чаплигін Іван Костянтинович, студент спеціальності 071 «Облік і оподаткування», Національний аерокосмічний університет ім. М. Є. Жуковського «Харківський авіаційний інститут», м. Харків, Україна.

Chaplyhin Ivan, student of 071 Accounting and Taxation Speciality, National Aerospace University «Kharkiv Aviation Institute», Kharkiv, Ukraine.

ORCID ID: 0000-0002-8447-4951

e-mail: iv.13.ch@gmail.com 
nancial results in the conditions of competitive environment is the conceptual aspects of their classification. The functioning of an enterprise largely depends on its ability to bring a sufficient level of income. The aim of the research is to define the concept of systematization of financial results of the enterprise in order to further improve the efficiency of accounting and analytical work of the organization, identify problems in the interpretation of the concept of «financial results» in order to improve their accounting, analysis and audit. The subject of the research is conceptual aspects of classification of financial results of domestic enterprises. The methods of the research: comparison, juxtaposition, systemic and analytical approaches, mean values, generalization and classification, dialectical and formal logic. The statement of basic materials. The article identifies the peculiarities of classification of financial results of the enterprise, defines existing shortcomings in the regulatory and legislative regulation of Ukraine regarding the terminology of financial results of the company, examines and summarizes approaches to the interpretation of the concept of «financial results», evaluates and analyzes the financial results of domestic business entities, measures are proposed to improve accounting, analytical and audit procedures for financial results and improve the business performance of organizations. The practical significance of the research lies in the possibility of applying the recommendations provided to improve accounting, analytical and audit procedures for financial results and improve the business efficiency of domestic enterprises. Conclusions and perspectives of further research. Classification of financial results of enterprises is the starting point for building their accounting, analysis and audit, but existing approaches to systematizing financial results contain many contradictory points, and therefore are imperfect. Classification features should cover a comprehensive study of financial results and ensure that they are grouped in the right context. The offered classification of financial results for the use of accounting, analysis and audit will increase the efficiency of accounting and analytical activities of organizations.

Key words:

financial results, systematization, accounting and audit, analysis, accounting and analytical activities.

\section{КОНЦЕПЦИЯ СИСТЕМАТИЗАЦИИ ФИНАНСОВЫХ РЕЗУЛЬТАТОВ ПРЕДПРИЯТИЯ: УЧЁТНО-АНАЛИТИЧЕСКИЕ АСПЕКТЫ ОБЕСПЕЧЕНИЯ}

Постановка проблемы. Понимание сущности финансовых результатов деятельности предприятий и использования действенных управленческих решений относительно будущего их развития ключевой залог повышения эффективности работы организаций. Одним из актуальных вопросов, касаемого учета, анализа и аудита финансовых результатов в условиях конкурентной среды, являются концептуальные аспекты их классификации. Функционирование предприятия в значительной степени зависит от его способности приносить достаточный уровень дохода. Целью статьи является определение концепции систематизации финансовых результатов предприятия для дальнейшего повышения эффективности учётно-аналитической работы организации, выявление проблем в трактовании понятия «финансовые результаты» с целью усовершенствования их учёта, анализа и аудита. Предмет исследования - концептуальные аспекты классификации финансовых результатов деятельности отечественных предприятий. Meтоды, использованные в исследовании: сравнение, сопоставление, системного и аналитического подходов, средних величин, обобщения и классификации, диалектической и формальной логики. Изложение основного материала. В статье выявлены особенности классификации финансовых результатов деятельности предприятия, определены существующие недостатки в нормативно-законодательном регулировании Украины по терминологии финансовых результатов фирмы, исследованы и обобщены подходы к трактованию понятия «финансовые результаты», осуществлено оценивание и анализ финансовых результатов отечественных субъектов хозяйствования, предложены меры по совершенствованию учётно-аналитических и аудиторских процедур относительно финансовых результатов и улучшения результативности бизнеса организаций. Практическое значение полученных результатов заключается в возможности применения предоставленных рекомендаций по совершенствованию учётно-аналитических и аудиторских процедур касательно финансовых результатов и повышения эффективности бизнеса отечественных предприятий. Bыводы исследования. Классификация финансовых результатов деятельности предприятий является исходным моментом построения их учёта, анализа и аудита, однако существующие подходы к систематизации финансовых результатов содержат множество спорных моментов, а потому являются несовершенными. Классификационные признаки должны охватывать комплексное изучение финансовых результатов и обеспечивать в нужном разрезе их группировки. Предложенная классификация финансовых результатов деятельности с целью их учёта, анализа и аудита позволит повысить эффективность учётно-аналитической деятельности организаций.

Ключевые слова:

финансовые результаты, систематизация, учёт и аудит, анализ, учётно-аналитическая деятель- 
Постановка проблеми. На сучасному етапі глобалізації однією з головних умов успішного функціонування суб'єкта господарювання, кінцевою метою його бізнесу є беззбитковість комерційної й іншої діяльності, відшкодування витрат власними доходами, забезпечення в певних розмірах прибутковості та рентабельності, а також їхнє збільшення.

Діяльність будь-якого підприємства залежить від його здатності приносити достатній рівень доходу, запорукою якого $є$ ефективна обліково-аналітична діяльність організації. В умовах середовища конкурентної боротьби підприємство зацікавлене в досягненні високих фінансових результатів.

Актуальність тематики дослідження пов'язана не тільки 3 важливістю фінансових результатів в економічному розвитку підприємств, але й невирішеністю багатьох проблем, у тому числі відсутності єдиного підходу до розкриття змісту поняття «фінансовий результат», неповноти нормативнозаконодавчої бази з питань обліку, аналізу та аудиту фінансових результатів, недосконалість сучасної концепції систематизації фінансових результатів тощо.

Аналіз останніх досліджень і публікацій. Проблематика трактування категорії та систематизації фінансових результатів діяльності підприємств знайшла відображення в багатьох працях сучасних вітчизняних науковців-економістів, зокрема Ф. Ф. Бутинця, Н. М. Бондаренко, Т. І. Ковальчука [1], I. Ю. Зудової, О. Г. Стась [3], В. П. Мазур [4], О. В. Мелень, О. В. Полтавець [5], О. В. Назаренко, Р. В. Лукаша [6], О. Сарапіної та Я. Кутишенко [10] тощо.

Незважаючи на те, що підходи до класифікації фінансових результатів існують в економічній літературі досить давно, вони досі містять багато спірних моментів, а тому $\epsilon$ недосконалими. Тому означена проблематика вимагає подальшого вивчення 3 урахуванням трансформаційних процесів в умовах ринкової економіки.

Метою статті с визначення концепції систематизації фінансових результатів підприємства для подальшого підвищення ефективності обліково-аналітичної роботи організації, виявлення проблем у трактуванні поняття «фінансові результати» 3 метою удосконалення їхнього обліку, аналізу та аудиту.
Виклад основного матеріалу дослідження. Для розроблення досконалих методик обліку, аналізу та аудиту фінансових результатів потрібно, насамперед, дослідити концепцію їх систематизації. Класифікація фінансових результатів, що здатна задовольняти інформаційні потреби користувачів на високому рівні, є одним із основних аспектів проведення обліково-аналітичних та аудиторських процедур на вітчизняних підприємствах. Тема фінансових результатів діяльності підприємства завжди актуальна, а також $є$ предметом постійного обговорення серед науковці та практиків у сфері економіки та управління підприємством. Тому для того, щоби виявити концепцію систематизації показників фінансового результату спочатку необхідно звернутися до наукових праць відомих вчених, які займалися дослідженням цього питання та проаналізувати термінологію заданої категорії.

Трактування поняття «фінансові результати» $є$ важливим аспектом у формуванні концепції систематизації фінансових результатів підприємства. Розуміння сутності цієї категорії і прийняття дієвих управлінських рішень для подальшого досягнення високих фінансових результатів - основна запорука збільшення ефективності бізнесу організацій.

Переважна кількість науковців здебільшого відносять появу поняття «фінансові результати» до часів виникнення початкових форм капіталу та товарного виробництва. В. П. Мазур у свої працях узагальнив різноманітні підходи до трактування змісту фінансових результатів науковими школами економічної теорії (табл. 1) [4].

Дослідження тлумачень, представлених у таблиці 1, показує, що в ході розвитку економічної теорії зміст і наповнення категорії «фінансові результати» трансформувалося. Спостерігається певний перехід від визначення фінансового результату, як прибутку, що $є$ джерелом багатства, до його тлумачення 3 погляду додаткової вартості, яка створюється працею найманих робітників [1].

Для детальнішого оцінювання сутності поняття «фінансові результати» проведемо порівняльний аналіз сучасних трактувань цієї категорії серед вітчизняних науковців, який представлено в таблиці 2. 
Т а б л и ц я 1 - Концепція трактування економічного змісту фінансових результатів різними науковими школами

\begin{tabular}{|c|c|c|}
\hline $\begin{array}{l}\text { № } \\
3 / \text { ח }\end{array}$ & $\begin{array}{l}\text { Назва школи еко- } \\
\text { номічної теорії }\end{array}$ & Концепція трактування змісту поняття «фінансовий результат» \\
\hline 1 & $\begin{array}{c}\text { Школа } \\
\text { меркантилізму }\end{array}$ & $\begin{array}{l}\text { Фінансові результати, що проявляються у вигляді прибутку, формуються в } \\
\text { сфері обігу та торгівлі, які } є \text { джерелом багатства }\end{array}$ \\
\hline 2 & $\begin{array}{l}\text { Школа } \\
\text { фізіократів }\end{array}$ & $\begin{array}{l}\text { Прибуток, як основна форма фінансових результатів, виникає за рахунок } \\
\text { природної родючості землі, тобто аграрне виробництво являється основ- } \\
\text { ним джерелом багатства }\end{array}$ \\
\hline 3 & $\begin{array}{l}\text { Школа } \\
\text { політекономії } \\
\text { (класична) }\end{array}$ & $\begin{array}{l}\text { Формування фінансових результатів відбувається в сфері виробництва, а } \\
\text { прибуток, як заробітна плата і рента, є частиною вартості, що в свою чергу } \\
\text { створюється працею }\end{array}$ \\
\hline 4 & $\begin{array}{c}\text { Школа } \\
\text { марксизму }\end{array}$ & $\begin{array}{l}\text { Основним джерелом формування фінансових результатів є додаткова вар- } \\
\text { тість, що створюється працею найманих працівників в процесі виробницт- } \\
\text { ва та реалізується через сферу обігу }\end{array}$ \\
\hline 5 & $\begin{array}{l}\text { Неокласична } \\
\text { школа }\end{array}$ & $\begin{array}{l}3 \text { одного боку, фінансові результати формуються за рахунок капіталу та } € \\
\text { ціною даного виробничого фактору, а з іншого, - формуються за рахунок } \\
\text { комплексу всіх задіяних виробничих факторів }\end{array}$ \\
\hline 6 & $\begin{array}{c}\text { Школа } \\
\text { інституціоналізму }\end{array}$ & $\begin{array}{l}\text { Фінансові результати формуються під впливом різних суспільних нееко- } \\
\text { номічних інститутів (НТП, держава, соціальні групи, профспілки тощо) }\end{array}$ \\
\hline
\end{tabular}
Джерело: розроблено авторами на підставі [4]

Т а б л и ц я 2 - Визначення поняття «фінансовий результат» різними науковцями

\begin{tabular}{|c|c|c|}
\hline $\begin{array}{l}\text { № } \\
3 / \text { ח }\end{array}$ & Автор & Сутність поняття «фінансовий результат» \\
\hline 1 & Ф. Ф. Бутинець [1] & Прибуток (збиток) від реалізації готової продукції (робіт, послуг) \\
\hline 2 & $\begin{array}{l}\text { Н. М. Бондаренко, } \\
\text { T. I. Ковальчук [1] }\end{array}$ & $\begin{array}{l}\text { Приріст (зменшення) вартості власного капіталу підприємства, який } \\
\text { виникає в процесі його підприємницької діяльності }\end{array}$ \\
\hline 3 & $\begin{array}{l}\text { О. В. Мелень, } \\
\text { О. В. Полтавець } \\
\text { [5] }\end{array}$ & $\begin{array}{l}\text { Отриманий в процесі господарської діяльності прибуток або збиток, } \\
\text { що розраховується як різниця між доходами та витратами відобра- } \\
\text { женими у звіті, який відбиває зміну власного капіталу за визначе- } \\
\text { ний період та виступає якісним або кількісним показником госпо- } \\
\text { дарчої діяльності підприємства }\end{array}$ \\
\hline 4 & $\begin{array}{l}\text { І. Ю. Зудова, } \\
\text { О. Г. Стась [3] }\end{array}$ & $\begin{array}{l}\text { Визначальний критерій ефективності господарювання, позитивне } \\
\text { значення якого визначає можливість подальшого розвитку } \\
\text { підприємства та створює запас фінансової стійкості, що дає фірмі } \\
\text { змогу оперативно реагувати на зміни у ринковій кон'юнктурі }\end{array}$ \\
\hline 5 & $\begin{array}{l}\text { О. В. Назаренко, } \\
\text { Р. В. Лукаш [6] }\end{array}$ & $\begin{array}{l}\text { Виражений в грошовій формі показник результативності діяльності } \\
\text { суб'єкта господарювання шляхом зіставлення визначених доходів } \\
\text { та витрат понесених на їхнє отримання, що може бути представле- } \\
\text { ний у формі прибутку або збитку }\end{array}$ \\
\hline
\end{tabular}

Джерело: розроблено авторами на підставі $[1,3,5,6]$

Незважаючи на різні формулювання, вітчизняні вчені та практики зводять визначення фінансових результатів переважно до поняття «прибуток або «збиток».

Проведений аналіз наукових праць дозволяє стверджувати, що сучасна концепція трактування сутності категорії «фінансовий результат» стосуються в основному визна- чення його як зміни капіталу та грошових коштів, як різниці між доходами і витратами на основі його розрахунку, як визначальний критерій ефективності бізнесу тощо.

Сутність фінансового результату діяльності також визначається через його економічні функції, які наведено в таблиці 3. 
Економічні функції фінансових результатів

\begin{tabular}{|c|c|l|}
\hline $\begin{array}{c}\text { № } \\
\text { 3/п }\end{array}$ & Функція & \multicolumn{1}{c|}{ Зміст } \\
\hline 1 & Регулювання & $\begin{array}{l}\text { Сутність цієї функції полягає в регулюванні грошових потоків і розподілі по } \\
\text { різним фондам }\end{array}$ \\
\hline 2 & Стимулювання & $\begin{array}{l}\text { Сутність цієї функції полягає в необхідності зростання прибутку для підви- } \\
\text { щення результативності діяльності підприємства }\end{array}$ \\
\hline 3 & Контролювання & Сутність цієї функції полягає в контролі за ефективністю бізнесу організації \\
\hline 4 & $\begin{array}{c}\text { Альтернативне } \\
\text { використання } \\
\text { ресурсів }\end{array}$ & $\begin{array}{l}\text { Сутність цієї функції полягає в пошуку альтернативних способів використан- } \\
\text { ня ресурсів }\end{array}$ \\
\hline
\end{tabular}

Джерело: розроблено авторами на підставі [2]

Отже, економічний зміст фінансових результатів полягає в тому, що вони є інструментами конкурентоспроможності підприємства, гарантом погашення зобов'язань перед державою, діловими партнерами та колективом працівників, а також джерелом розвитку суб' єкта господарювання.

Систематизація фінансових результатів діяльності будь-якого суб'єкта господарювання значно залежить від нормативної бази, що регулює правові та економічні відносини підприємства 3 державою, з іншими організа- ціями, 3 трудовим колективом тощо. Тому одним із важливих питань також є огляд нормативно-правової бази з обліку, аналізу та аудиту фінансових результатів господарської діяльності підприємства.

В Україні структуру нормативноправового регулювання щодо фінансових результатів можна умовно поділити на шість рівнів, які містять законодавчі акти, що регламентують обліково-аналітичні та аудиторські процедури (рисунок 1).

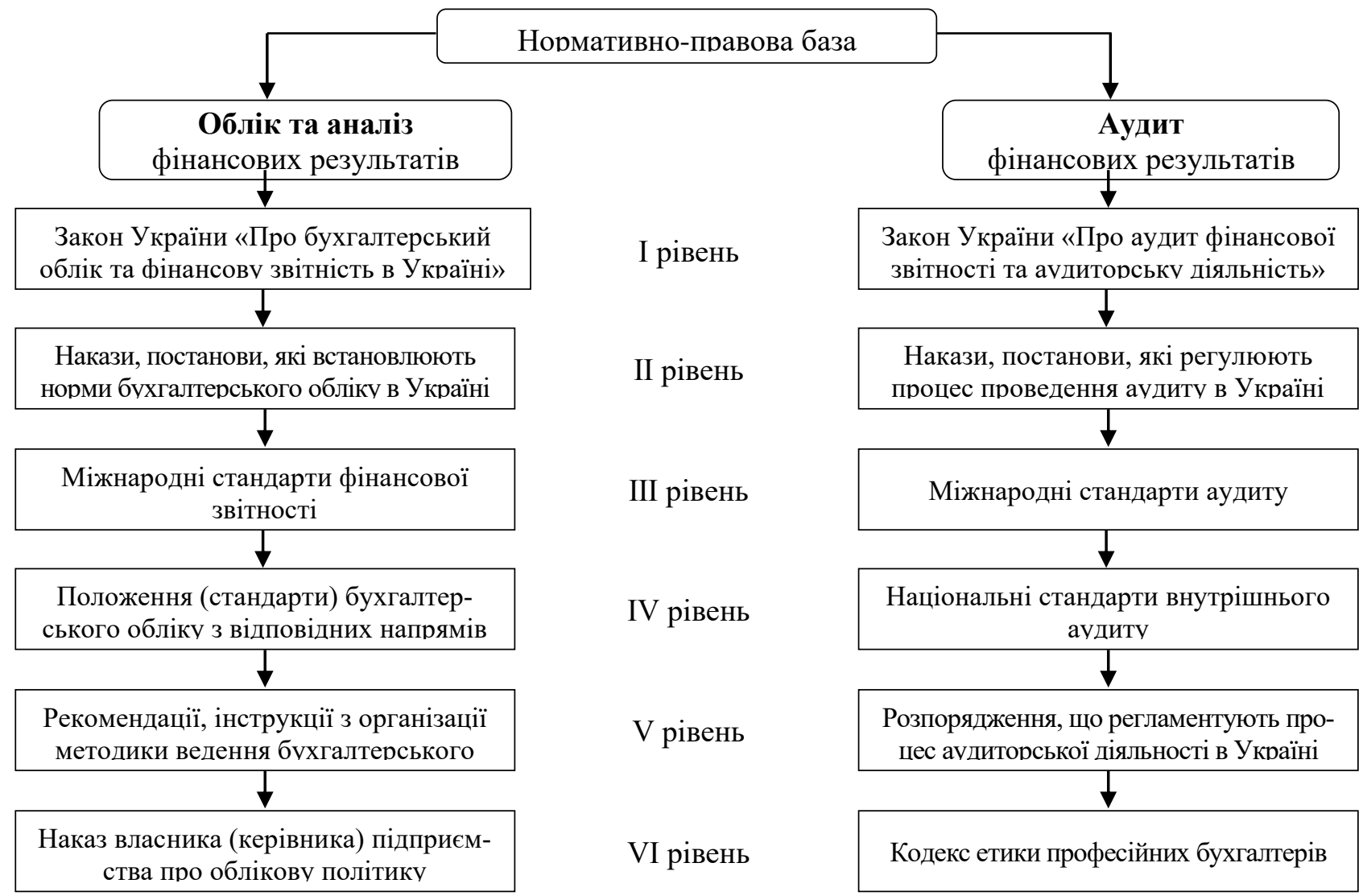

Рисунок 1 - Рівні нормативно-правового регулювання обліку, аналізу та аудиту фінансових результатів в Україні Джерело: розроблено авторами на підставі [9] 
Вивчення нормативно-правового регулювання показало, що в законодавстві України термін «фінансові результати» детально не розглядається, а лише обгрунтовується зміст категорій «прибуток» та «збиток» [1].

Так, згідно з НП(С)БО1 «Загальні вимоги до фінансової звітності», фінансовим результатом діяльності підприємства може бути визначений прибуток або збиток. Прибуток це сума, на яку доходи перевищують пов'язані з ними витрати, а збиток, у свою чергу, - перевищення суми витрат над сумою доходу, для отримання якого вони були здійснені [7].

Варто зазначити, що вищезазначені нормативно-законодавчі акти взагалі не містять систематизації фінансових результатів, яка могла бути застосована для створення дієвих інформаційних обліково-аналітичних моделей. Класифікація фінансових результатів, насамперед, потрібна для застосування відповідних рішень користувачами, а тому повинна мати цілий комплекс за певними ознаками, що збільшить аналітичність наведеної інформації [5].

Також для виявлення особливостей концепції систематизації фінансових результатів діяльності й запропонування рекомендацій щодо вдосконалення обліковоаналітичних та аудиторських процедур і покращення ефективності бізнесу необхідно проаналізувати отримані фінансові результати вітчизняних організацій за останні роки. Розмір фінансових результатів до оподаткування підприємств України наведено в таблиці 4.

Т а б л и ц я 4 - Фінансові результати до оподаткування підприсмств України за 2018-2020 рр.

У тисячах грн

\begin{tabular}{|c|c|c|c|c|c|c|}
\hline \multirow[b]{3}{*}{ Роки } & \multicolumn{4}{|c|}{ Підприємства, які одержали: } & \multirow{3}{*}{$\begin{array}{c}\text { Фінансовий } \\
\text { результат } \\
\text { (сальдо) до } \\
\text { оподаткування }\end{array}$} & \multirow[b]{3}{*}{$\begin{array}{c}\text { Темп при- } \\
\text { росту, } \%\end{array}$} \\
\hline & \multicolumn{2}{|c|}{ прибуток } & \multicolumn{2}{|c|}{ збиток } & & \\
\hline & $\begin{array}{c}\text { у \% до за- } \\
\text { гальної кіль- } \\
\text { кості } \\
\text { підприємств } \\
\end{array}$ & $\begin{array}{l}\text { фінансовий } \\
\text { результат }\end{array}$ & $\begin{array}{c}\text { у \% до за- } \\
\text { гальної кіль- } \\
\text { кості } \\
\text { підприємств } \\
\end{array}$ & $\begin{array}{l}\text { фінансовий } \\
\text { результат }\end{array}$ & & \\
\hline 2018 & 74,30 & 668893496,8 & 25,70 & 299681235,1 & 369212261,7 & - \\
\hline 2019 & 74,00 & 869642104,6 & 26,00 & 256598069,1 & 613044035,5 & 66,04 \\
\hline 2020 & 65,20 & 411809900,0 & 34,80 & 318491900,0 & 93318000,0 & $-74,73$ \\
\hline
\end{tabular}

Примітка. На офіційному веб-сайті Державної служби статистики України на час написання статті інформація за 2020 рік інформація надана тільки за січень-вересень цього року.

Джерело: розроблено авторами на підставі [8]

Дані таблиці 4 показують, що загальна питома вага вітчизняних підприємств, які отримали прибуток до оподаткування, має тенденцію зниження за аналізовані роки. Так, загальна частка таких підприємств зменшу- ється з 74,30\% за 2018 рік до $65,20 \%$ у 2020 році.

Розмір фінансових результатів після оподаткування підприємств України наведено в таблиця 5.

Т а б л и ц я 5 - Чистий прибуток (збиток) підприємств України за 2018-2020 рр.

\begin{tabular}{|c|c|c|c|c|c|c|}
\hline \multirow{4}{*}{ Роки } & & & & & & У тисячах грн \\
\hline & \multicolumn{4}{|c|}{ Підприємства, які одержали: } & \multirow{3}{*}{$\begin{array}{c}\text { Фінансовий } \\
\text { результат } \\
\text { (сальдо) до } \\
\text { оподаткування }\end{array}$} & \multirow{3}{*}{$\begin{array}{c}\text { Темп } \\
\text { приросту, \% }\end{array}$} \\
\hline & \multicolumn{2}{|c|}{ прибуток } & \multicolumn{2}{|c|}{ збиток } & & \\
\hline & $\begin{array}{c}\text { y \% до загальної } \\
\text { кількості } \\
\text { підприємств } \\
\end{array}$ & $\begin{array}{c}\text { фінансовий } \\
\text { результат }\end{array}$ & $\begin{array}{c}\text { y \% до загальної } \\
\text { кількості } \\
\text { підприємств }\end{array}$ & $\begin{array}{l}\text { фінансовий } \\
\text { результат }\end{array}$ & & \\
\hline 2018 & 73,90 & 584358002,5 & 26,08 & 296052534,4 & 288305468,1 & - \\
\hline 2019 & 73,60 & 772019623,4 & 26,42 & 248240621,9 & 523779001,5 & 81,68 \\
\hline 2020 & 64,50 & 209117400,0 & 35,50 & 298942000,0 & $-89824600,0$ & $-131,16$ \\
\hline
\end{tabular}

Примітка. На офіційному веб-сайті Державної служби статистики України на час написання статті інформація за 2020 рік інформація надана тільки за січень-вересень цього року. 
За даними табл. 5 видно, що загальна частка прибуткових підприємств в Україні має також спадаючу тенденцію у досліджуваному періоді. Питома вага організацій, що отримали чистий прибуток, усього по еконо- міці знижується 3 73,90\% у 2018 році до $64,50 \%$ за 2020 рік.

Визначимо загальну динаміку фінансових результатів діяльності вітчизняних підприємств за 2018-2020 рр. на рисунок 2.

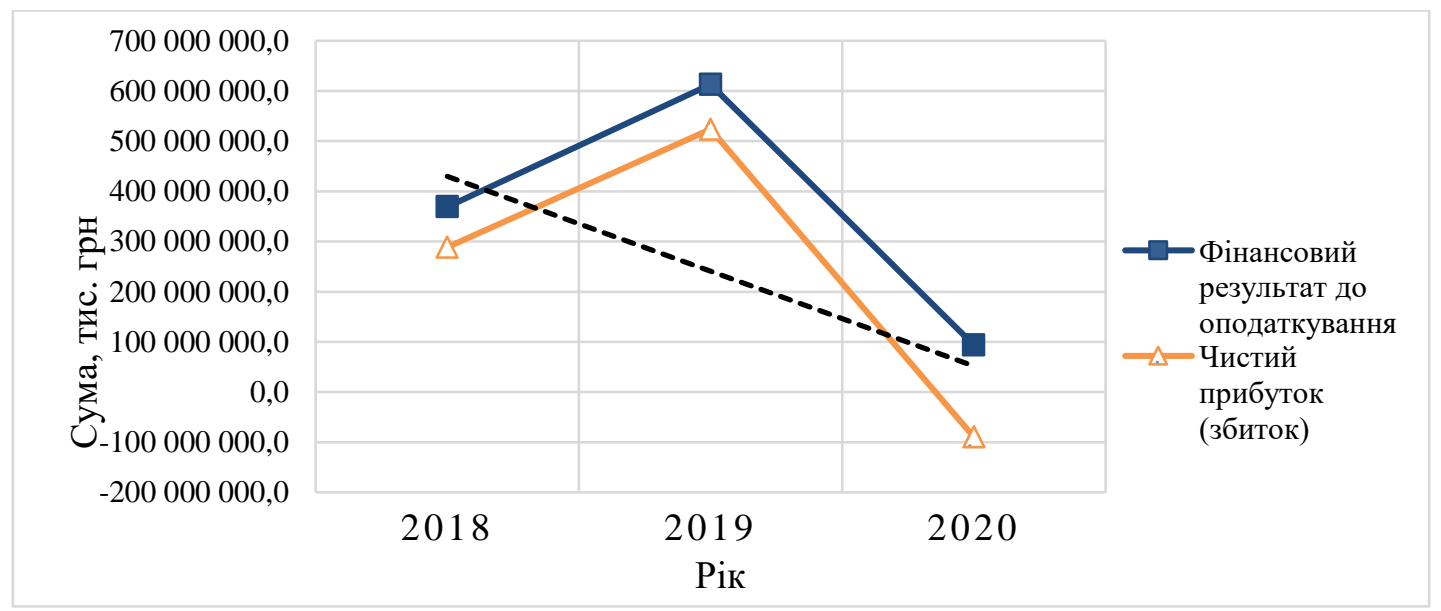

Рисунок 2 - Динаміка фінансових результатів підприємств України за 2018-2020 pp. Джерело: розроблено авторами на підставі [8]

Факторний аналіз дає можливість припустити, що останні три місяці 2020 року не зможуть змінити ситуацію, і в кінцевому підсумку загальна сума фінансового результату українських підприємств за цей період буде набагато менше, ніж за попередні роки. Тому за даними рис. 2 можемо стверджувати, що прибуток підприємств України в період 3 2010 р. по 2020 р. має неоднозначну тенденцію, що також підтверджується спадаючою лінією тренду. Так, у 2020 році відбулось різке скорочення фінансових результатів і формування значної суми збитків. Це свідчать про руйнівний вплив, що досі спричинясться відповідними епідеміологічними подіями, результати якого вітчизняним підприємствам ще не вдалося компенсувати заробленими прибутками в останні роки.

Практичну значимість класифікації фінансових результатів переоцінити неможливо По-перше, вона забезпечує групування та систематизацію даних про фінансові результати, що виступають основними об'єктами обліково-аналітичної діяльності підприємств, у різних інформаційних розтинах залежно від цільової спрямованості їхнього використання. По-друге, класифікація значною мірою визначає основні напрями організації обліку, аналізу та аудиту фінансових результатів на прикладному рівні, оптимальний ступінь співвідношення й взаємозв'язку окремих їх- ніх елементів, вибір відповідних методів і моделювання управлінських рішень [10].

Систематизація фінансових результатів підприємств має бути теоретично обгрунтованою та застосування іiї на практиці повинно визначатися необхідністю.

Узагальнивши сучасні підходи до трактування фінансових результатів та проаналізувавши їхнє отримання вітчизняними підприємствами за останні роки, можна запропонувати наступну класифікацію фінансових результатів, що представлена в таблиці 6.

Запропонована систематизація розширює важливі ознаки для підвищення та забезпечення обліково-аналітичної інформації про фінансові результати. Наприклад, класифікаційна ознака для розширення аналітичних здібностей управлінського обліку, пропонує впровадження вертикального та горизонтального групування.

Така класифікація має принципові властивості для забезпечення та збільшення оперативності інформації у фінансових результатах обліково-аналітичної діяльності, оскільки складання фінансових результатів горизонтальним методом передбачає вивчення витрат, доходів і фінансових результатів в розрізі їх видів на рівні компанії в загалі, основуючись на розроблених планах на рік 3 щомісячної розробкою даних, а вертикальний принцип формування фінансових результатів забезпечить достовірні аналітичні дані на рівні класу відповідальності [5]. 
Т а б л и ц я 6 - Концепція систематизації фінансових результатів підприсмств

\begin{tabular}{|c|c|}
\hline \multicolumn{2}{|c|}{ Класифікація фінансових результатів } \\
\hline Обліковий аспект & Аналітичний аспект \\
\hline $\begin{array}{l}\text { 1. У залежності від виду діяльності: } \\
\text { - операційний; } \\
\text { - фінансовий; } \\
\text { - інвестиційний. }\end{array}$ & $\begin{array}{l}\text { 1. Відповідно до методики розрахунку: } \\
\text { - валовий; } \\
\text { - чистий; } \\
\text { - маржинальний. }\end{array}$ \\
\hline $\begin{array}{l}\text { 2. Відповідно до джерела формування: } \\
\text { - від реалізації товарів, робіт, послуг; } \\
\text { - від фінансових операцій. }\end{array}$ & \multirow{2}{*}{$\begin{array}{l}\text { 2. У залежності від відповідності плану: } \\
\text { - недоотриманий; } \\
\text { - плановий; } \\
\text { - надлишковий. }\end{array}$} \\
\hline 3. У залежності від періоду формування: & \\
\hline $\begin{array}{l}\text { - минулий; } \\
\text { - звітний; } \\
\text { - майбутній. }\end{array}$ & $\begin{array}{l}\text { 3. Відповідно до бази оцінки: } \\
\text { - обліковий; } \\
\text { - податковий. }\end{array}$ \\
\hline $\begin{array}{l}\text { 4. Відповідно до способу використання: } \\
\text { - нерозподілений; } \\
\text { - розподілений. }\end{array}$ & $\begin{array}{l}\text { 4. У залежності від особливості оподаткування: } \\
\text { - оподаткований; } \\
\text { - звільнений від оподаткування. }\end{array}$ \\
\hline $\begin{array}{l}\text { 5. У залежності від макроекономічної ситуації: } \\
\text { - нестійкий; } \\
\text { - стабільний. }\end{array}$ & $\begin{array}{l}\text { 5. Відповідно до мети управління: } \\
\text { - за горизонтальним групуванням; } \\
\text { - за вертикальним групуванням. } \\
\end{array}$ \\
\hline $\begin{array}{l}\text { 6. Відповідно до характеру отримання: } \\
\text { - негативний; } \\
\text { - нульовий; } \\
\text { - позитивний. }\end{array}$ & $\begin{array}{l}\text { 6. У залежності від можливості отримання: } \\
\text { - малоймовірний; } \\
\text { - імовірний } \\
\text { - високовірогідний. }\end{array}$ \\
\hline 7. У залежності від групи доходів: & 7. Відповідно до сукупності: \\
\hline - цільові; - нейтральні; - додаткові. & - окремий; - загальний. \\
\hline
\end{tabular}

\section{Висновки та перспективи подальших} досліджень. Отже, дослідження концепції систематизації фінансових результатів підприємств дає можливість усвідомити причини необхідності постійного вдосконалення обліковоаналітичних та аудиторських процедур для визначення напрямів подальшого розвитку бізнесу організацій.

Систематизація фінансових результатів діяльності підприємств є вихідним моментом побудови їх обліку, аналізу та аудиту, проте наявні підходи щодо класифікації фінансових результатів містять багато суперечливих моментів, а тому є недосконалими. Класифікаційні ознаки мають охоплювати комплексне вивчення фінансових результатів та забезпечувати в потрібному розрізі їхне групування.

Проведене оцінювання концепції трактування поняття «фінансові результати» дозволяє відокремити три точки зору науковців, як: нізації;

- підсумки (результати) діяльності орга-

- прибуток (збиток) підприємства;

- приріст (зменшення) власного капіталу.

Нормативно-правове регулювання обліку, аналізу та аудиту фінансових результатів визначається чинним законодавством, однак у ньому взагалі відсутня класифікація фінансових результатів, яка могла бути використана для створення ефективних інформаційних обліково-аналітичних моделей. Тому авторами була запропонована класифікація фінансових результатів у розрізі певних ознак, що відображає обліковий та аналітичний аспекти, розуміння яких необхідно для прийняття керівництвом i користувачами відповідних рішень.

Для вдосконалення обліково-аналітичних та аудиторських процедур щодо фінансових результатів і покращення ефективності бізнесу вітчизняних підприємств доцільними вважаємо такі рекомендації:

1) закріплення на законодавчому рівні сутності такої категорії, як «фінансові результати», та уточнення переліку показників, що характеризують фінансові результати діяльності підприємств;

2) розширення класифікаційних ознак, що дасть змогу у майбутньому розробити результативні механізми та систему управління певними складовими фінансових результатів для регулювання їхнього рівня в довгостроковій та короткостроковій перспективі;

3) розроблення спеціальних регістрів, а саме: аналітичних відомостей про фінансові 
результати щодо узагальнення облікової інформації для задоволення інформаційних потреб різних користувачів.

Напрямами подальших досліджень буде оцінювання ефективності запропонованої класифікації фінансових результатів та розроблення моделі діджиталізації їхнього обліку та аудиту.

\section{Література}

1. Бондаренко Н. М., Ковальчук Т. І. Економічна сутність фінансових результатів діяльності підприємства. Вісник Дніпропетровського університету. Серія: Економіка. 2014. № 8 (4). C. 75-81.

2. Єфімова О. В. Фінансовий аналіз: сучасний інструментарій для прийняття економічних рішень. Москва: Омега-Л, 2015. 352c.

3. Зудова І. Ю., Стась О. Г. Сутність та значення фінансових показників в системі функціонування підприємства. Молодий вчений. 2017. № 10 (50). С. 893-897.

4. Мазур В. П. Економічний зміст поняття фінансових результатів сільськогосподарської діяльності. Облік і фінанси АПК. 2011. № 3. С. 68-71.

5. Мелень О. В., Полтавець О. В. Фінансові результати діяльності підприємства: визначення, класифікація, управління. Вісник НТУ «Харківський політехнічний інститут». Серія: Економічні науки. 2017. № 46 (1267). С. 109-114.

6. Назаренко О. В., Лукаш Р. В. Фінансові результати: сутність та особливості організації бухгалтерського обліку. Інвестииії: практика та досвід. 2018. № 22. С. 19-25.

7. Національне положення (стандарт) бухгалтерського обліку 1 «Загальні вимоги до фінансової звітності»: затверджене наказом Міністерства фінансів України від 07.02.2013 р. № 73, зі змінами та доповненнями. URL: https://zakon.rada.gov.ua/laws/show/z0336-13

8. Офіційний веб-сайт Державної служби статистики України. URL: https://www.ukrstat.gov.ua/
9. Офіційний веб-сайт Міністерства фінансів України. URL: https://mof.gov.ua/

10. Сарапіна О., Кутишенко Я. Вдосконалення обліку фінансових результатів. Міжнародний збірник наукових працьь. 2014. № 2. C. 101-104.

\section{References}

1. Bondarenko, N. M., Kovalchuk, T. I. (2014) Economic essence of financial results of the enterprise activities. Bulletin of Dnipropetrovsk University. Series: Economics, 8 (4), 75-81.

2. Efimova, O. V. (2015). Financial analysis. modern tools for making economic decisions. Moscow: Omega-L, 352.

3. Zudova, I. Y. Stas, O. G. (2017) The Essence and significance of financial indicators in the system of functioning of the enterprise. A young scientist, № 10 (50), 893-897.

4. Mazur, V. P. (2011). Economic content of the concept of financial results of agricultural activities. Accounting and finance of the AIC, 3, 5257.

5. Melen, O. V., Poltavets, O. V. (2017) Financial results of the business of the enterprise: definition, classification, management by them. Bulletin of NTU «Kharkiv Polytechnic Institute». Series: Economic Sciences, 46 (1267), 109-114.

6. Nazarenko, O. V., Lukash, R. V. (2018). Financial results: the essence and features of the of accounting organization. Investment: practice and experience, 22, 19-25.

7. National regulation (standard) of accounting 1 «General requirements for financial reporting»: approved by the order of the Ministry of Finance of Ukraine dated 07.02.2013 No. 73, with changes and additions. Retrieved from: https://zakon.rada.gov.ua/laws/show/z0336-13

8. Official website of the State Statistics Service of Ukraine. Retrieved from: https://www.ukrstat.gov.ua/

9. Official website of the Ministry of Finance of Ukraine. Retrieved from: https://mof.gov.ua/

10. Sarapina, O., Kutishenko, Y. (2014). Improving accounting for financial results. International collection of scientific papers, 2, 101-104.

Стаття прийнята

до друку: 30.03.2021p.

до редакції : 11.01.2021 p.

Бібліографічний опис для цитування :

Ліхоносова Г. С. Концепція систематизації фінансових результатів підприємства: обліково-аналітичні аспекти забезпечення / Г. С. Ліхоносова, І. К. Чаплигін // Часопис економічних peформ. - 2021. - № 1 (41). - C. 58-66. 